\title{
Corrections
}

\section{Novel truncating and missense mutations of the KCC3 gene associated with Andermann syndrome}

In the article "Novel truncating and missense mutations of the KCC3 gene associated with Andermann snydrome" (Neurology 2006;66:1044-1048) by G. Uyanik et al., there is an error on page 1048, in the first sentence of the fourth full paragraph. The sentence should read as follows:

"Furthermore, alteration of the same arginine residue with an exchange to glutamine within the homologous gene SLC12A3 (also known as NCCT) encoding the thiazide-sensitive sodium-chloride-cotransporter has been linked to Gitelman syndrome (hypokalemic metabolic alkalosis with hypocalciuria and hypomagnesemia associated to muscle weakness and cramps; OMIM 263800), ${ }^{20}$ suggesting an important role of this arginine residue for the function of the wildtype gene product."

In addition, a corrected version of supplemental figure E-3 was posted at www.neurology.org on September 22, 2006.

The authors regret the errors.

\section{Superficial siderosis}

In the Views \& Reviews "Superficial siderosis" by N. Kumar et al. (Neurology 2006;66:1144-1152), reference 10 should be replaced with the following:

10. Offenbacher H, Fazekas F, Reisecker F, Schimdt R, Payer F, Lechner H. Superficial siderosis of the spinal cord: a rare cause of myelopathy diagnosed by MRI. Neurology 1991;41:1987-1989.

The authors regret the error.

\section{Epidemiology of vestibular vertigo: A neurotologic survey of the general population}

In the article "Epidemiology of vestibular vertigo: A neurotologic survey of the general population" by H.K. Neuhauser et al. (Neurology 2005;65:898-904), there are errors in the Abstract and Discussion sections.

Abstract: The 8th line should read "sensitivity of 84\%"; in the 9th and 10th lines, the lifetime prevalence of vestibular vertigo should be $7.4 \%$, the 1 -year prevalence should be $4.9 \%$, and the incidence should be $1.4 \%$. Accordingly, the second to last line of the abstract should read "affecting $5 \%$ of adults in 1 year."

Discussion, first paragraph: As in the Abstract, the lifetime prevalence of vestibular vertigo should be $7.4 \%$, the 1-year prevalence should be $4.9 \%$, and the incidence should be $1.4 \%$.

The authors regret the errors.

\section{Iatrogenic Creutzfeldt-Jakob disease: The waning of an era}

In the Views \& Reviews "Iatrogenic Creutzfeldt-Jakob disease: The waning of an era," by P. Brown et al. (Neurology 2006;67:389393), the name of the third author (Michael Preece) was misspelled. In addition, the authors inadvertently overlooked a second Brazilian case of Creutzfeldt-Jakob disease due to contaminated human growth hormone. The patient was treated with hormone prepared in the United States for 16 years, and the interval between the treatment mid-point to onset of symptoms was 28 years. The clinical presentation included mental and behavorial deterioration, somnolence, and gait ataxia, and the duration of illness was 10 months. A detailed case report was published in 2002 by Caboclo et al. ${ }^{1}$

The authors regret the errors.

1. Caboclo LOSF, Huang N, Lepski GA, et al. Iatrogenic Creutzfeldt-Jakob disease following human growth hormone therapy. Arq Neuropsiquiatr 2002;60:458-461. 


\title{
Neurology
}

\author{
Iatrogenic Creutzfeldt-Jakob disease: The waning of an era \\ Neurology 2006;67;1528-1528-c \\ DOI 10.1212/01.wnl.0000250611.54151.a5
}

This information is current as of October 23, 2006

Updated Information \&

Services

References

Permissions \& Licensing

Reprints including high resolution figures, can be found at: http://n.neurology.org/content/67/8/1528.4.full

This article cites 1 articles, 0 of which you can access for free at: http://n.neurology.org/content/67/8/1528.4.full\#ref-list-1

Information about reproducing this article in parts (figures,tables) or in its entirety can be found online at:

http://www.neurology.org/about/about_the_journal\#permissions

Information about ordering reprints can be found online:

http://n.neurology.org/subscribers/advertise

Neurology ${ }^{\circledR}$ is the official journal of the American Academy of Neurology. Published continuously since 1951, it is now a weekly with 48 issues per year. Copyright. All rights reserved. Print ISSN: 0028-3878. Online ISSN: 1526-632X.

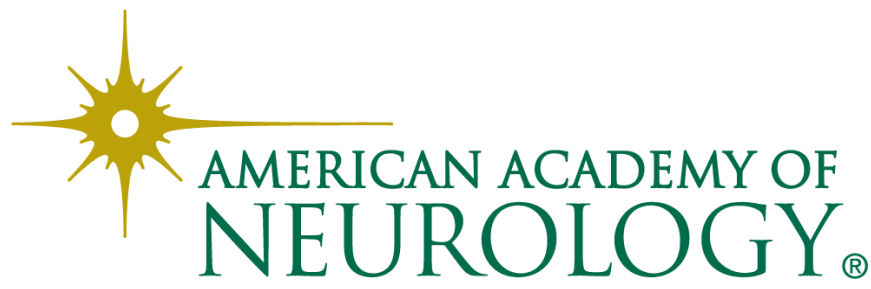

